\title{
PENERAPAN MEDIA KEPING BERWARNA TERHADAP HASIL BELAJAR PESERTA DIDIK PADA MATA PELAJARAN MATEMATIKA DI SEKOLAH DASAR (Studi Eksperimen Pada Bilangan Bulat Di Kelas IV SDN Sukasari Kec. Cipatat)
}

\author{
Oleh \\ Sri Rohartati \\ Universitas Langlangbuana \\ srinchi@ymail.com
}

Diterima 24 Desember 2016, direvisi 30 Januari 2017, diterbitkan 31 Agustus 2017

\begin{abstract}
The low learning outcomes in mathematics at the State Elementary School in the material Sukasari summation of integers and the results of their study have not yet reached KKM (minimum completeness criteria) to overcome these problems, the researchers used instructional media as a tool to improve the learning outcomes of students. The research design used in this study are nonequivalent control group design. This research was conducted in two classes, experimental and control classes. Both of these classes are treated differently, grade control using conventional learning while the experimental class using the Media Chips Color. Data collection techniques used in this research is the observation and tests. To collect data in this study, the use of research instrument shaped observation sheets and test questions. Based on the analysis of data there are significant differences between the results of the pretest and posttest experimental class and there are differences in learning outcomes between the control group and the experimental group after treatment so that there are significant media use colored tile to the study of students in mathematics in elementary school then the hypothesis can be accepted.
\end{abstract}

Keywords: Media Keping Color; Learning outcomes; Subjects Mathematics.

\section{PENDAHULUAN}

Pendidikan adalah usaha sadar dan terencana. Pendidikan merupakan pengalaman belajar diberbagai lingkungan yang berlangsung sepanjang hayat dan berpengaruh positif bagi perkembangan individu. Karena dalam pendidikan mengandung transformasi pengetahuan, nilai-nilai, dan keterampilan yang diperlukan. (Redja Mudyahardjo, 2001). Oleh sebab itu, pendidikan memiliki peran penting 
dalam menciptakan sumber daya manusia yang berkualitas, salah satu cirinya adalah dimilikinya kemampuan berpikir kritis.

Pendidikan di sekolah dasar merupakan lembaga yang dikelola dan diatur oleh pemerintah dan oleh swastayang bergerak dibidang pendidikan yang diselenggarakan secara formal yang berlangsung selama 6 tahun dari kelas 1 sampai kelas 6.Pendidikan di sekolah dasar merupakan pendidikan anak yang berusia antara 7 sampai 13 tahun.Pendidikan di Sekolah Dasar di ajarkan mata pelajarannya beragam dan harus mampu dikuasai oleh peserta didik. Keberagaman ini menyebabkan peserta didik harus lebih fokus dalam mengikuti proses kegiatan pembelajaran di dalam kelas. tentunya hal ini menjadi tantangan bagi pendidik untuk mampu merubah paradigma lama dan membuat paradigma baru yang dapat dan mampu diterima peserta didik di sekolah.

Pendidikan berusaha mencerdaskan kehidupan bangsa tentunya dari berbagai aspek.Cerdas bukan hanya mampu mengetahui dan bisa melakukan sesuatu.Cerdas lebih mengarah kepada mengetahui serta mampu memilih mana yang baik dan benar dan mana yang buruk.Hamalik (dalam Nunuk Suryani dan LeoAgung, 2012: 146) mengemukakan bahwa penggunaan media pembelajaran dalam proses belajar-mengajar dapat membangkitkan keinginan dan minat baru peserta didik, membangkitkan motivasi dan rangsangan kegiatan belajar dan bahkan membawa pengaruh-pengaruh psikologis terhadap peserta didik. Terlebih peserta didik di usia sekolah dasar masih belum mampu berpikir abstrak sehingga dibutuhkan media/alat peraga sebagai alat bantu dalam pembelajaran yang dapat memperjelas materi pelajaran.

Selain itu, permasalahan pengelolaan proses belajar mengajar materi matematika di Sekolah Dasar adalah kurangnya pengetahuan pendidik tentang bagaimana cara membuat dan menggunakan media dalam pembelajaran matematika, padahal dalam materi pembelajaran Matematika media sangat diperlukan. Melihat bahwa anak usia Sekolah Dasar dalam memahami konsep-konsep matematika masih sangat memerlukan kegiatankegiatan yang berhubungan dengan benda nyata (pengalaman-pengalaman konkret) yang dapat diterima akal peserta didik. Maka peranan media dalam mata pelajaran matematika adalah untuk mempermudah pemahaman dan meningkatkan hasil belajar peserta didik Sekolah Dasar terhadap mata pelajaran matematika yang belum mampu berpikir abstrak. Salah satu materi pelajaran matematika yang dianggap sulit oleh peserta didik usia Sekolah Dasar adalah konsep penjumlahan bilangan bulat, dalam hal ini terdapat dua konsep yaitu bilangan bulat positif dan bilangan bulat negatif yang merupakan konsep yang abstrak. Agar kedua konsep tersebut dapat dipahami, maka diperlukan suatu media yang dapat mengubah konsep abstrak tersebut menjadi kongkret yang sesuai dengan perkembangan pemikiran peserta didik di Sekolah Dasar.

Berdasarkan hasil observasi di Sekolah Dasar Negeri Sukasari peserta didik menemukan kesulitan dalam pembelajaran matematika materi penjumlahan bilangan bulat dan masih belum mencapai KKM (Kriteria Ketuntasan Minimal). Oleh karena itu untuk mengatasi masalah tersebut pendidik harus memahami perkembangan peserta didik usia Sekolah Dasar yang belum mampu berfikir secara abstrak. Untuk mengatasi masalah abstraksi tersebut, maka pendidik harus menggunakan media pembelajaran sebagai alat untuk mempermudah pemhaman mata pelajaran matematika yaitu tentang bilangan bulat.Salah satunya dengan menggunakan media keping berwarna yang menekankan pada hasil belajar peserta didik.Banyak sekali media yang bisa diterapkan dan memungkinkan pendidik untuk menyampaikan materi pembelajaran matematika secara menarik dan menyenangkan. Namun dalam pemilihan media yang diterapkan harus disesuaikan dengan 
karakteristik peserta didiknya, dimana pada usia peserta didik di Sekolah Dasar masih senang belajar sambil bermain sehingga alat peraga yang digunakan dalam pembelajaran matematika khususnya pada penjumlahan bilangan bulat yaitu media keping berwarna sangat cocok untuk diterapkan. Berdasarkan permasalahan di atas peneliti merasa terpanggil untuk melakukan penelitian ini.

\section{PEMBAHASAN}

\subsection{Media Keping Berwarna}

Anak usia SD dapat menyerap pengalaman dengan mudah melalui bendabenda yang bersifat konkret atau nyata Yuliani 2009 (dalam Arisnani 2014). Menurut Rusman (2013: 213) media relia merupakan alat bantu visula dalam pembelajaran yang berfungsi memberikan pengalaman langsung. Relia ini merupakan model dan objek nyata dari suatu benda seperti mata uang, tumbuhan, binatang dan sebagainya. Sri Anitah (2012: 24) juga menjelaskan relia atau disebut juga objek adalah benda yang sebenarnya dalam bentuk utuh misalnya: orang, binatang, rumah, dan sebagainya.

Menurut Mulyani Sumantri, dkk 2004 (Arisnani 2014) mengemukakan bahwa secara umum media konkret berfungsi sebagai:

a. Alat bantu untuk mewujudkan situasi belajar mengajar yang efektif

b. Bagian integral dari keseluruhan situasi mengajar.

c. Meletakkan dasar-dasar yang konkret dan konsep yang abstrak sehingga dapat mengurangi pemahaman yang bersifat verbalisme.

d. Mengembangkan motivasi belajar peserta didik

e. Mempertinggi mutu belajar mengajar.

Berdasarkan pendapat di atas untuk meningkatkan hasil belajar dan untuk mendukung meningkatkan kegiatan belajar mengajar hendaknya menggunakan media konkret / benda konkret sehingga peserta didik paham dengan materi pembelajaran.Maka dalam penelitian ini peneliti menggunakan media konkret yakni keping berwarna.

Keping berwana yang digunakan dalam pembelajaran ini adalah kancing berwarna.Kancing merupakan salah satu benda yang biasanya digunakan sebagai kelengkapan pada pakaian.Kancing biasanya digunakan pada kemeja yang dilengkapi dengan lubang untuk mengaitkannya.Ukuran kancing sangatlah bervariasi mulai dari yang kecil sampai yang besar dan warnanya pun bermacam-macam.

Ternyata benda kecil ang sering kita jumpai untuk perlengkapan bajuu ini dapat dimanfaatkan sebagai salah satu alat peraga atau media pembelajaran matematika dalam melakukan operasi hitung penjmlahan bilangan bulat. Prabawanto (dalam Nurlaela, 2011) menyatakan bahwa untuk dapat menjelaskan konsep penjumlahan bilangan bulat pada peserta didik sekolah dasar dapat menggunakan media/alat peraga. Media yang dapat dipilih adalah garis bilangan atau dengan menggunakan manik-manik untuk dijadikan media pembelajaran pada pembelajaran operasi hitung penjumlahan bilangan bulat, dan manikmanik yang dipilih adalah keping berwana.

\subsection{Langkah-langkah Penggunaan Media Keping Berwarna}

Operasi penjumlahan bilangan bulat.Ada beberapa prinsip yang perlu diperhatikan untuk menggunakan media kepingberwarna ini dalam melakukan operasi hitung penjumlahan bilangan bulat.

a. Keping berwarna merah mewakili bilangan bulat positif, dan keping berwarna hitam mewakili bilangan bulat negatif.

b. Untuk setiap kepingmerah dan hitam yang berpasangan, maka pasangan tersebut bersifat netral atau bernilai nol $(0)$ 
Operasi hitung bilangan bulat dengan keping berwarna atau keeping berwarna yaitu penggabungan kepingberwana merah dan hitam yang disesuaikan dengan bilangan bulat positif dengan bilangan bulat negatif. Misalkan keping berwarna merah untuk bilangan bulat positif dan keping berwarna hitam untuk bilangan bulat negatif. Kita ambil sebuah contoh misalnya hitunglah $2+(-3)$

Penyelesaian :

a. Simpanlah keping berwarna merah (positif) sebanyak 2 buah letakkan sejajar.

b. Kemudian simpanlah kepingberwarna hitam (negatif) tepat di bawah keping berwarna merah dan harus sejajar.

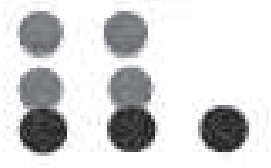

c. Terlihat bahwa ada 2 buah pasangan keping berwarna merah dan hitam. Pasangan ini bersifat netral (0), sehingga harus di keluarkan atau diambil

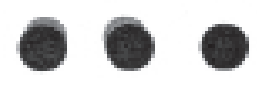

d. Setelah 2 buah pasangan kepingberwarna merah dan hitam di keluarkan atau diambil, menyisakan 1 buah keping berwana hitam (negatif). Peragaan ini menunjukkan bahwa $2+$ $(-3)=-1$

\subsection{Hasil Belajar}

Hasil belajar adalah kemampuan yang dimiliki peserta didik setelah ia menerima pengalaman belajar melalui tes yang telah diberikan. Jika hasil tes bagus maka peserta didik dikatakan berhasil dalam belajarnya, sebaliknya jika hasil tes jelek maka peserta didik tersebut dikatakn kurang berhasil dalam belajarnya. Kemajuan prestasi belajar peserta didik tidak saja diukur dari tingkat penguasan ilmu pengetahuan tetapi juga sikap (afektif) dan keterampilan (psikomotor). Dengan demikian penilaian hasil belajar peserta didik mencakup segala hal yang dipelajari di sekolah, baik itu menyangkut pengetahuan (kognitif), sikap (afektif) dan keterampilan (psikomotor).

Hasil belajar adalah sejumlah pengalaman yang diperoleh peserta didik yang mencakup ranah kognitif, afektif dan psikomotor. Belajar tidak hanya penguasaan konsep teori mata pelajaran saja, tapi juga penguasaaan kebiasaan, persepsi kesenangan, minat bakat, penyesuaian sosial, macam-macam keterampilan, cita-cita, keinginan dan harapan.Hal tersebut senada dengan pendapat Oemar Hamalik (dalam Rusman 2015: 67) yang menyatakan bahwa "hasil belajar itu dapat terlihat dari terjadinya perubahan dari persepsi dan perilaku, termasuk juga perbaikan perilaku."Menurut Juliah (dalam Asep dan Abdul 2013: 15) hasil belajar adalah segala sesuatu yang menjadi milik peserta didik sebagai akibat dari kegiatan belajar yang dilakukannya.

Secara sederhana, hasil belajar dapat disimpulkan bahwa hasil belajar adalah kemampuan yang diperoleh anak setelah melalui kegiatan belajar. Karena belajar itu sendiri merupakan suatu proses dari seseorang yang berusaha untuk memperoleh suatu bentuk perubahan prilaku yang relatif menetap.

\subsection{Pembelajaran Matematika Di Sekolah Dasar}

Matematika merupakan salah satu bidang studi yang ada pada semua jenjang pendidikan, mulai dari tingkat sekolah dasar hingga perguruan tinggi. Bahkan matematika diajarkan di taman kanak-kanak secara informal.

Pada usia peserta didik sekolah dasar (7-8 tahun hingga 12-13 tahun), menurut teori kognitif Piaget termasuk pada tahap operasional konkret. Berdasarkan perkembangan kognitif 
ini, maka anak usia sekolah dasar pada umumnya mengalami kesulitan dalam memahami matematika yang bersifat abstrak. Karena keabstrakannya matematika dianggap tidak mudah untuk dipahami oleh peserta didik sekolah dasar pada umumnya. Bidang studi matematika merupakan salah satu komponen pendidikan dasar dalam bidang-bidang pengajaran. Bidang studi matematika ini diperlukan untuk proses perhitungan dan proses berpikir yang sangat dibutuhkan orang dalam menyelesaikan berbagai masalah.

Kata matematika berasal dari bahasa Latin, manthanein atau mathema yang berarti "belajar atau hal yang dipelajari” sedang dalam bahasa Belanda, matematika disebut wiskunde atau ilmu pasti. Matematika memiliki bahasa dan aturan yang terdefinisi dengan baik, penalaran yang jelas dan sistematis, dan struktur atau keterkaitan antarkonsep yang kuat.Unsur utama pekerjaan matematika adalah penalaran dedukatif yang bekerja atas dasar asumsi (kebenaran konsistensi).

Dengan demikian, matematika merupakan cara berpikir logis yang dipersentasikan dalam bilangan, ruang, dan bentuk dengan aturanaturan yang telah ada yang tak lepas dari aktivitas insani tersebut. Pada hakikatnya matematika tidak terlepas dari kehidupan sehari-hari, dalam arti matematika memiliki kegunaan yang praktis dalam kehidupan seharihari. Semua masalah kehidupan yang membutuhkan pemecahan secara cermat dan teliti mau tidak mau harus berpaling kepada matematika

\subsection{Eksperimen Pada Bilangan Bulat}

Pelaksanaan Penelitian ini menggunakan media pembelajaran keping berwarna dengan materi yang diberikan adalah penjumlahan bilangan bulat.

\subsubsection{Hasil Observasi}

\section{a. Afektif}

Hasil observasi terhadap sikap peserta didik disajikan dalam bentuk tabel sebagai berikut.

\section{Hasil Observasi Peserta DidikTerhadap Kritera Aspek Penilaian Afektif}

\begin{tabular}{llllllll}
\hline No Indikator & & \multicolumn{4}{c}{ Bobot } & & $\begin{array}{r}\text { Jumlah } \\
\text { Penilaian }\end{array}$ \\
\cline { 3 - 6 } & & $\mathbf{5}$ & $\mathbf{4}$ & $\mathbf{3}$ & $\mathbf{2}$ & $\mathbf{1}$ & $\begin{array}{r}\text { Didik } \\
\text { Didik }\end{array}$ \\
\hline 1 & Menerima & 2 & 16 & 12 & & & 30 \\
2 & Menjalankan & 2 & 10 & 16 & 2 & & 30 \\
3 & Menghargai & 8 & 12 & 7 & 3 & & 30 \\
4 & Menghayati & 4 & 10 & 14 & 2 & 30 \\
5 & Mengamalkan & 2 & 10 & 14 & 4 & & 30 \\
\hline
\end{tabular}

Berdasarkan tabel di atas dari hasil observasi terhadap sikap peserta didik maka dapat disimpulkan sebagai berikut.

1. Terhadap indikator menerima materi pembelajaran dari 30 peserta didik, dua orang peserta didik menerima pelajaran dengan nilai sangat baik, 16 orang peserta didik menerima pelajaran dengan nilai baik dan 12 orang peserta didik menerima pelajaran dengan nilai cukup baik.

2. Terhadap indikator menjalankan proses pembelajaran dari 30 peserta didik, dua peserta didik menjalankan proses pembelajaran dengan nilai sangat baik, 10 peserta didik menjalankan proses pembelajaran dengan nilai baik, 16 peserta didik menjalankan proses pembelajaran dengan nilai cukup baik dan dua peserta didik menjalankan proses 
pembelajaran dengan nilai kurang baik.

3. Terhadap indikator menghargai proses pembelajaran dari 30 orang peserta didik, delapan orang peserta didik menghargai proses pembelajaran dengan nilai sangat baik, 12 orang peserta didik memiliki sikap menghargai proses pembelajaran dengan nilai baik, tujuh orang peserta didik memiliki sikap menghargai proses pembelajaran dengan nilai cukup baik dan tiga orang peserta didik memiliki sikap menghargai proses pembelajaran dengan nilai kurang baik.

4. Terhadap indikator menghayati proses pembelajaran dari 30 orang peserta didik, dua orang peserta didik menghayati proses pembelajaran dengan nilai sangat baik, 10 orang peserta didik menghayati proses pembelajaran dengan nilai baik dan 14 orang peserta didik menghayati proses pembelajaran dengan nilai cukup baik dan dua orang peserta didik menghayati proses pembelajaran dengan nilai kurang baik.

5. Terhadap indikator mengamalkan materi pembelajaran dari 30 peserta didik, dua orang peserta didik mengamalkan materi pembelajaran dengan nilai sangat baik, 10 peserta didik mengamalkan materi pembelajaran dengan nilai baik, 14 orang peserta didik mengamalkan materi pembelajaran dengan nilai cukup baik dan empat orang peserta didik mengamalkan materi pembelajaran dengan niali kurang baik.

\section{b. Psikomotor}

Hasil observasi terhadap keterampilan peserta didik disajikan dalam bentuk tabel sebagai berikut.

\section{Hasil Observasi Peserta DidikTerhadap Kriteria Aspek Penilaian Psikomotor}

\begin{tabular}{|c|c|c|c|c|c|c|c|}
\hline \multirow[t]{2}{*}{ No } & \multirow{2}{*}{$\begin{array}{l}\text { Indikator } \\
\text { Penilaian }\end{array}$} & \multicolumn{5}{|c|}{ Bobot } & \multirow{2}{*}{$\begin{array}{c}\text { Jumlah } \\
\text { Peserta } \\
\text { Didik }\end{array}$} \\
\hline & & 5 & 4 & 3 & 2 & 1 & \\
\hline 1 & Mengamati & 6 & 10 & 14 & & & 30 \\
\hline 2 & Menanya & 4 & 10 & 12 & 4 & & 30 \\
\hline 3 & Mencoba & 12 & 12 & 6 & & & 30 \\
\hline 4 & Mengolah & 4 & 13 & 10 & 3 & & 30 \\
\hline 5 & Menyaji & 8 & 9 & 7 & 6 & & 30 \\
\hline 6 & Menala & 7 & 15 & 6 & 2 & & 30 \\
\hline 7 & Mencipta & 2 & 10 & 14 & 4 & & 30 \\
\hline
\end{tabular}

Dari hasil tabel di atas dari hasil observasi terhadap Keterampilan peserta didik dapat disimpulkan sebagai berikut:

1) Terhadap indikator mengamati materi pembelajaran dari 30 peserta didik, enam orang peserta didik mengamati materi pembelajaran dengan nilai sangat baik, 10 orang peserta didik dengan nilai baik dan 14 orang peserta didik mengamati materi pembelajaran dengan nilai cukup baik.

2) Terhadap indikator menanya dari 30 peserta didik, empat orang peserta didik memiliki keterampilan bertanya dengan nilai sangat baik, 12 peserta didik memiliki keterampilan bertanya dengan nilai baik dan 10 peserta didik memiliki keterampilan bertanya dengan nilai cukup baik dan empat orang peserta didik memiliki keterampilan bertanya dengan nilai kurang baik.

3) Terhadap indikator mencoba mempratekan media pembelajaran dari 30 pesera didik, 12 peserta didik mencoba mempraktikan media pembelajaran, dengan nilai sangat baik, 12 peserta didik mencoba memperaktekan media pembelajaran dengan nilai baik dan enam peserta 
didik mencoba media pembelajaran dengan nilai cukup baik.

4) Terhadap indikator mengolah materi pembelajaran dari 30 peserta didik, empat orang peserta didik mengolah materi pembelajaran dengan nilai sangat baik, 13 orang peserta didik mengolah materi pembelajaran dengan nilai baik, 10 orang peserta didik mengolah materi pembelajaran dengan nilai cukup baik dan tiga orang peserta didik mengolah materi pembelajaran dengan nilai kurang baik.

5) Terhadap indikator menyaji materi pembelajaran dari 30 peserta didik, delapan orang peserta didik mengolah materi pembelajaran dengan nilai sangat baik, sembilan orang peserta didik mengolah materi pembelajaran dengan nilai baik, tujuh orang peserta didik mengolah materi pembelajaran dengan nilai cukup baik dan enam orang peserta didik mengolah materi pembelajaran dengan nilai kurang baik.

6) Terhadap indikator menalar materi pembelajaran dari 30 peserta didik, tujuh orang peserta didik menalar materi pembelajaran dengan nilai sangat baik, 15 orang peserta didik menalar materi pembelajaran dengan nilai baik, enam orang peserta didik menalar materi pembelajaran dengan nilai cukup baik dan dua orang peserta didik menalar materi pembelajaran dengan nilai kurang baik.

7) Terhadap indikator mencipta suasana belajar dari 30 peserta didik, dua orang peserda didik mencipta suasana belajar dengan nilai sangat baik, 10 orang peserta didik mencipta suasana belajar dengan nilai baik, 14 orang peserta didik mencipta suasana belajar dengan nilai cukup baik dan empat orang peserta didik mencipta suasana belajar dengan nilai kurang baik.

\subsubsection{Hasil Tes Peserta Didik Pada Mata Pelajaran Matematika}

\section{a. Pretest}

Pertama yang dilakukan dalam penelitian adalah memberikan soal pretest kepada kelas eksperimen.Hal tersebut bertujuan untuk mengukur kemampuan awal peserta didik pada pembelajaran matematika materi penjumlahan bilangan bulat.Adapun hasil dari pretest kelas eksperimen adalah sebagai berikut.

\section{Hasil Pretest Peserta Didik Kelas Eksperimen}

\begin{tabular}{lccccccccccc}
\hline \multirow{2}{*}{ Hasil } & \multicolumn{1}{c}{ Soal } \\
\cline { 2 - 12 } & \multicolumn{1}{c}{ C1 Pengetahuan } & \multicolumn{1}{c}{ C2 Pemahaman } & \multicolumn{3}{c}{ C3 Penerapan } \\
\hline Nomor Soal & $\mathbf{1}$ & $\mathbf{2}$ & $\mathbf{4}$ & $\mathbf{3}$ & $\mathbf{6}$ & $\mathbf{8}$ & $\mathbf{5}$ & $\mathbf{7}$ & $\mathbf{9}$ & $\mathbf{1 0}$ \\
Jawaban benar & 20 & 14 & 11 & 16 & 18 & 12 & 13 & 9 & 8 & 12 \\
Jawaban Salah & 10 & 16 & 19 & 14 & 12 & 18 & 17 & 21 & 22 & 18 \\
\hline
\end{tabular}

Berdasarkan data pada tabel tersebut maka dapat dipresentasikan dengan perhitungan sebagai berikut.

Rumus $=\frac{\mathrm{N}-1}{\mathrm{~N}} \times 100$
Keterangan :

$\mathrm{N}-1=$ jumlah peserta didik yang menjawab soal benar

$\mathrm{N}=$ jumlah seluruh peserta didik

$100=100 \%$ 
Berdasarkan data terhadap soal pretest dengan kisi-kisi soal materi penjumlahan bilangan bulat diatas maka dapat disimpulkan secara rinci sebagai berikut.

Hasil prest peserta didik terhadap pengetahuan tentang materi penjumlahan bilangan bulat yang terdapat pada nomor satu, dua dan empat adalah sebagai berikut:

1) Terhadap soal nomor satu $67 \%$ peserta didik menjawab benar dan $33 \%$ peserta didik menjawab salah

2) Terhadap soal nomor dua $47 \%$ peserta didik yang menjawab benar dan $53 \%$ peserta didik menjawab salah.

3) Terhadap soal nomor empat $37 \%$ peserta didik menjawab benar dan $63 \%$ peserta didik menjawab salah.

Hasil pretest peserta didik terhadap pemahaman tentang materi penjumlahan bilangan bulat yang terdapat pada nomor tiga, enam dan delapan adalah sebagai berikut:

1. Terhadap soal nomor tiga 53\% peserta didik menjawab benar dan $47 \%$ peserta didik menjawab salah.

2. Terhadap soal no enam $60 \%$ peserta didik menjawab benar dan $40 \%$ peserta didik menjawab salah.

3. Terhadap soal nomor delapan $40 \%$ peserta didik menjawab benar dan $60 \%$ peserta didik menjawab salah.
Hasil pretest peserta didik terhadap penerapan tentang materi penjumlahan bilangan bulat yant terdapat pada nomor lima, tujuh, sembilan dan 10 adalah sebagai berikut:

1) Terhadap soal nomor lima $43 \%$ peserta didik menjawab benar dan $57 \%$ peserta didik menjawab salah.

2) Terhadap soal nomor tujuh $30 \%$ peserta didik menjawab benar dan $70 \%$ peserta didik menjawab salah.

3) Terhadap soal nomor sembilan $27 \%$ peserta didik menjawab benar dan $73 \%$ peserta didik menjawab salah.

4) Terhadap soal nomor sepuluh $40 \%$ peserta didik menjawab benar dan $60 \%$ peserta didik menjawab salah.

Berdasarkan rincian di atas maka dapat disimpulkan banyak peserta didik yang menjawab benar terhadap kriteria pengetahuan adalah $50 \%, 51 \%$ peserta didik yang menjawab benar terhadap kriteria pemahaman dan $35 \%$ peserta didik yang menjawab benar terhadap kriteria penerapan.

\section{b. Posttest}

Setelah diberikan pretest pada kelas eksperimen, selanjutnya peneliti memberi soal posttest untuk mengukur keberhasilan kelas eksperimen setelah diberi perlakuan atau treatment dengan menggunakan media keping berwarna.Adapun hasil dari posttest kelas eksperimen adalah sebagai berikut.

\section{Hasil Posttest Peserta Didik Kelas Eksperimen}

\begin{tabular}{lccccccccccc}
\hline & \multicolumn{1}{c}{ Soal } \\
\cline { 2 - 13 } & \multicolumn{1}{c}{ C1 Pengetahuan } & \multicolumn{1}{c}{ C2 Pemahaman } & \multicolumn{3}{c}{ C3 Penerapan } \\
\hline Nomor Soal & $\mathbf{1}$ & $\mathbf{2}$ & $\mathbf{4}$ & $\mathbf{3}$ & $\mathbf{6}$ & $\mathbf{8}$ & $\mathbf{5}$ & $\mathbf{7}$ & $\mathbf{9}$ & $\mathbf{1 0}$ \\
Jawaban benar & 28 & 20 & 20 & 28 & 21 & 20 & 18 & 25 & 17 & 16 \\
Jawaban Salah & 2 & 10 & 10 & 2 & 9 & 10 & 12 & 5 & 13 & 14 \\
\hline
\end{tabular}


Berdasarkan data pada tabel tersebut maka dapat dipresentasikan dengan perhitungan sebagai berikut.

Rumus : $\frac{\mathrm{N}-1}{\mathrm{~N}} \times 100$

Keterangan :

$\mathrm{N}-1=$ jumlah peserta didik yang menjawab soal benar

$\mathrm{N}=$ jumlah seluruh peserta didik

$100=100 \%$

Berdasarkan data terhadap soal posttest dengan kisi-kisi soal materi penjumlahan bilangan bulat diatas maka dapat disimpulkan secara rinci sebagai berikut.

Hasil posttest peserta didik terhadap pengetahuan tentang materi penjumlahan bilangan bulat yang terdapat pada nomor satu, dua dan empat adalah sebagai berikut:

1) Terhadap soal nomor satu $93 \%$ peserta didik menjawab benar dan $7 \%$ peserta didik yang menjawab salah.

2) Terhadap soal nomor dua $67 \%$ peserta didik menjawab benar dan $33 \%$ peserta didik menjawab salah.

3) Terhadap soal nomor empat $67 \%$ peserta didik menjawab benar dan $33 \%$ peserta didik menjawab salah.

Berdasarkan rincian di atas maka dapat disimpulkan banyak peserta didik yang menjawab benar terhadap kriteria pengetahuan adalah $76 \%, 77 \%$ peserta didik yang menjawab benar terhadap kriteria pemahaman dan $63 \%$ peserta didik yang menjawab benar terhadap kriteria penerapan.

\section{SIMPULAN}

Berdasarkan hasil penelitian dan pembahasan dapat disajikan hal-hal sebagai berikutmaka dapat disimpulkan bahwa berdasarkan hasil analisis data terdapat perbedaan hasil belajar antara kelas kontrol dan kelas eksperimen setelah perlakuan.Hasil belajar kelas eksperimen lebih baik dari hasil belajar kelas kontrol, sehingga terdapat pengaruh penggunaan media keeping berwarna terhadap hasil belajar peserta didik pada mata pelajaran matematika di Sekolah Dasar maka hipotesis dapat diterima.

\section{DAFTAR PUSTAKA}

Ahmad S (2013). Teori belajar dan pembelajaran di sekolah dasar.Jakarta. Kencana Prenada Media Group.

Arif S S (2012). Media pendidikan.Depok.PT Rajagrafindo Persada.

Arikunto S (2013). Prosedur penelitian suatu pendekatan praktik. Jakarta. Rineka Cipta

Arisnani (2014).Peningkatan kemampuan klasifikasi melalui media benda konkret pada anak kelompokA1 di RA Al Husna Yogyakarta.Skripsi UNY. Tidak diterbitkan.

Asep J \& Abdul H (2013).Evaluiasi pembelajaran.Yogya.Multi.

Nunuk S \& Leo A (2012).Strategi belajar mengajar.Yogyakarta. Penerbit Ombak.

Nurlela Y (2011). Penggunaan alat peraga kancing berwarna untuk meningkatkan pemahaman matematika tentang bilangan bulat. Skripsi UPI. Tidak diterbitkan

Priyanto D (2010). Paham analia statistik dengan spss.Yogyakarta.Medikom.

Rusman (2013).Model-model pembelajaran mengembangkan profesionalisme guru. Jakarta: Raja Grafindo Persada.

Rusman (2014).Model-model pembelajaran. Jakarta. Raja Grafindo Persada. 
Sugiyono, 2014.Metode penelitian pendidikan pendekatan kuantitatif, kualitatitf dan $r \quad \& \quad d$. CV, Bandung.Alfabeta.

Syaiful B \& Aswan Z (2010).Strategi belajar mengajar. Jakarta. PT Rineka Cipta.
Wina S (2012). Media komunikasi pembelajaran. Jakarta. Kencana.

Zainal A (2013). Model-model, media, dan strategi pembelajaran konstektual (Inovatif). Bandung. CV Yrama Widya. 